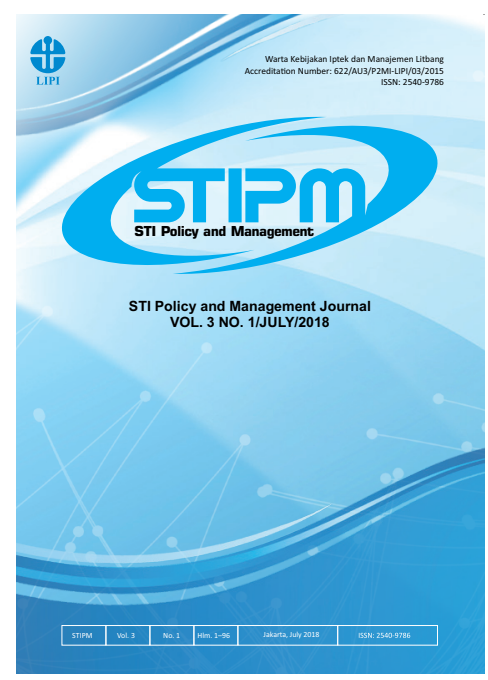

Journal of STI Policy and Management

Publication details, including instructions for authors and subscription information: http://www.stipmjournal.org/

\title{
Technology Transfer from Public Research Institute to Community: A Case Study
}

Wati Hermawati

Research Center for STI Policy and Management - LIPI

Version of record first published: 15 July 2019

To cite this article: Hermawati, W. (2019). Technology Transfer from Public Research Institute to Community: A Case Study. Journal of STI Policy and Management, 4(1), 1-15

To link to this article: http://dx.doi.org/10.14203/STIPM.2019.150

ISSN 2540-9786 (Print); ISSN 2502-5996 (online)

Accreditation Number: 21/E/KPT/2018

Full terms and conditions of use: https://creativecommons.org/licenses/by-nc-sa/4.0/

You are free to:

- Share : copy and redistribute the material in any medium or format

- Adapt : remix, transform, and build upon the material

- The licensor cannot revoke these freedoms as long as you follow the license terms.

Under the following terms:

Attribution - You must give appropriate credit, provide a link to the license, and indicate if changes were made. You may do so in any reasonable manner, but not in any way that suggests the licensor endorses you or your use.

NonCommercial - You may not use the material for commercial purposes.

ShareAlike - If you remix, transform, or build upon the material, you must distribute your contributions under the same license as the original.

No additional restrictions - You may not apply legal terms or technological measures that legally restrict others from doing anything the license permits.

Notices:

- You do not have to comply with the license for elements of the material in the public domain or where your use is permitted by an applicable exception or limitation.

- No warranties are given. The license may not give you all of the permissions necessary for your intended use. For example, other rights such as publicity, privacy, or moral rights may limit how you use the material.

- If you copy the dataset merely to extract the uncopyrightable data elements would not need permission to do so. However, if you republish the full dataset or using the copyrightable data layers require a permission from PAPPIPTEK-LIPI. 


\title{
JOURNAL OF SCIENCE, TECHNOLOGY AND INNOVATION POLICY AND MANAGEMENT (STIPM JOURNAL), Volume 04, Issue 01, July 2019
}

\author{
FOREWORD by EDITOR-in-CHIEF
}

We are very pleased to inform the readers that Journal of Science, Technology, \& Innovation Policy and Management (STIPM Journal) Vol. 4, No. 1, July 2019 edition is now ready for public reading and views. STIPM Journal is an online research journal managed by the Research Center for Science, Technology, and Innovation Policy and Management, Indonesian Institute of Sciences (RC-STIPM-LIPI).

The journal provides scientific information that needed mostly by the research scholars as well as STI policy makers. As a peer reviewed journal, STIPM provides free access to research thoughts, innovation, and original discoveries. In this issue, we bring together research findings on development and adoptation of science, technology, and innovation policy and management from Malaysia and Indonesia.

First article is composed by Wati HERMAWATI entitled Technology Transfer from Public Research Institute to Community: A Case Study. This research article examines the technology transfer mechanisms into practical applications of the community. The success of technology transfer to community itself were demonstrated by the increased ability of recipients namely SMEs and farmers to replicate the technologies, increased their production, enlarge their market as well as increased new knowledge, skills, and productivity.

Second research article entitled A Scientometric Study on Biodiesel Development in Indonesia. This article is presented by Mesnan SILALAHI et al. The article describes the results of scientometric studies in the energy sector, especially in the field of biodiesel in Indonesia by using a mixed method through content analysis and in-depth interview. Quantitative research uses bibliometric basics and content analysis, where text mining is triangulated with the results from in-depth interview with several prominent Indonesian researchers in this field. Content analysis is conducted by topic modeling method by analysing the papers' abstract. This article reports on the results of a scientometric study, based on publications indexed in Scopus in the energy sector, especially in the field of biodiesel in Indonesia.

Nor Ashikin Mohamed YUSOF et al. present an article entitled Theoretical and Practical Gaps in Policy Making Process in Five Organizations. This article reports case studies involving five national policy documents and internal policies at several key governmental department and organizations. The findings from the study enables the researchers to make a comparison between the theory of policy making and the practice of policy making in Malaysia. The findings show that there is still a huge gap between theory and practice in policy making and policy studies in Malaysia.

The fourth article with the title Innovative Strategy to Disseminate Science Information to Policy makers is presented by Azmi HASSAN. There exists a huge gap between science and technology discovery and the formulation of public policy mostly due to the poor understanding on how to disseminate the 
news not only to policy makers but also to the general public. To bring accurate, relevant information from the front lines of research to the policy makers, this paper describes how innovative strategies that use the media as the conduit are formulated in more systematic ways.

Dian KUSUMANINGRUM et al. present an article entitled Structural Equation Model: Intention to Use Mobile Banking of Bottom of Pyramid Customer. The purposes of the study are to identify the predicting factors influencing the intention to use mobile banking and empirically validate a model explaining the behavioral intention to use it, especially on the bottom of pyramid (BOP) segment. The model used was structural equation model (SEM) based on partial least square (PLS). The data used for developing the model was based on a survey to 100 BOP households. The results show that the variables that have the highest significant effect on BOP's customer intention to use mobile banking are involuntary barriers, followed by perceived risk, and attitude. This result can be further used by researchers and mobile banking providers to evaluate the existing mobile banking services to improve its contribution in providing better market penetration and more appropriate financial services for BOP and ultimately financial inclusion in Indonesia.

Lastly, Karlina SARI et al. present an article entitled Indonesia in Functional Food Industry: Market or Player? This paper presents the overview of functional food industry in Indonesia. It analyzes the prospect of Indonesian functional food industry from demand, supply, and regulation perspective. The result of this study is Indonesia should have a good prospect as both the market and the player in functional food industry. Currently, baby food and toddler are Indonesia's biggest market of functional food for baby formula milk and baby food. Another functional food market segment prospective to be penetrated is elderly who have bigger risk of disease, such as hypertension and arthritis

The journal is indexed by Google Scholar, ISJD, IPI, DOAJ, BASE, and OCLC World Cat, which makes wider journal dissemination. We would like to express our immense gratitude to our international editorial board members, reviewers, and authors for their contribution to this issue. We hope this publication will prove useful for readers and contribute to the enhancement of science, technology, and innovation. We expect that STIPM will always provide a higher scientific platform for authors and readers with a comprehensive overview of the most recent STI Policy and Management research and development at the national, regional, dan international level.

Jakarta, July 2019

Editor-In-Chief 



\section{JOURNAL OF STI POLICY AND MANAGEMENT}

Volume 4, Number 1, July 2019

\section{LIST OF CONTENTS}

Technology Transfer from Public Research Institute to Community: A Case Study

Wati Hermawati.

Scientometric Study on Biodiesel Development in Indonesia

Mesnan Silalahi, Agus Santoso dan Dudi Hidayat.

Theoretical and Practical Gaps in Policy Making Process in Five Organizations

Nor Ashikin Mohamed Yusof, Sri Widias Asnam, Aini Suzila Anas, Nur Suraya Mustapha,

Natrah Emran, Nor Azalina Azman

Innovative Strategy to Disseminate Science Information to Policy Makers

Azmi Hassan

Bottom of Pyramid Customer Intention to Use Mobile Banking: Structural Equation Model

Dian Kusumaningrum, Dewi Saraswati, Seprianus.

Drivers of Industry Convergence: The Case of Functional Food Industry in Indonesia

Karlina Sari, Dian Prihadyanti, Dudi Hidayat 


\title{
in STI POLICY AND MANAGEMENT \\ LIPI Journal homepage: http://www.stipmjournal.org
}

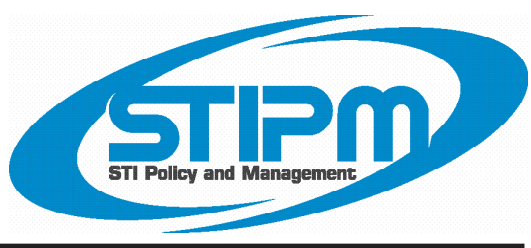

\section{Technology Transfer from Public Research Institute to Community: A Case Study}

\author{
Wati Hermawati \\ Research Center for STI Policy and Management - LIPI \\ wherma2007@yahoo.com; Phone:+6281314134000
}

\begin{tabular}{|c|c|}
\hline ARTICLE INFO & ABSTRACT \\
\hline $\begin{array}{l}\text { Article History: } \\
\text { Received : } 07 \text { November } 2018 \\
\text { Revised : } 07 \text { November } 2018 \\
\text { Accepted : } 23 \text { November } 2018 \\
\text { Available online : } 15 \text { July } 2019\end{array}$ & $\begin{array}{l}\text { Public funded research and development (R\&D) institutes need } \\
\text { to play a more active role in maximizing the utilization of their } \\
\text { innovation or research results. One of the benefits of } R \& D \\
\text { innovation result is in the form of economic, social, environmental } \\
\text { and cultural benefits for the improvement of human quality of life. }\end{array}$ \\
\hline $\begin{array}{l}\text { Keywords: } \\
\text { Technology transfer } \\
\text { Public research institutes } \\
\text { Communities } \\
\text { Innovation }\end{array}$ & $\begin{array}{l}\text { Drawing from evidence of the case studies of R\&D projects at public } \\
\text { research institute 'A' in Indonesia, we examined the technology } \\
\text { transfer mechanisms into practical applications of the community. } \\
\text { The mixed-method with good blend of qualitative and quantitative } \\
\text { analysis is used in the case study. The case study demonstrates that } \\
\text { there are five types of mechanisms for the technology transfer in this } \\
\text { institution, e.g. direct transfer, through cooperation and interaction } \\
\text { with multi stakeholders, patent and licensing, document transfer, } \\
\text { and dissemination activities. The success of technology transfer to } \\
\text { community were demonstrated by the increased ability of recipients } \\
\text { namely SMEs and farmers to replicate the technologies, increased } \\
\text { their production, enlarge their market as well as increased new } \\
\text { knowledge, skills, productivity, fertility of their rice fields and } \\
\text { decreased the use of chemical fertilizers by } 40 \% \text {, also increased } \\
\text { their household's income by average about } 30 \% \text {. }\end{array}$ \\
\hline
\end{tabular}

C2019 PAPPIPTEK-LIPI All rights reserved

\section{A. INTRODUCTION}

In developing countries, public research institutes (PRIs) are large beneficiaries of public investments in research and development (R\&D) activities (Cuciureanu \& Ungur, 2014; Zuniga \& Correa, 2013; Maass, 2003), it is therefore also known as public funded R\&D institutes. Many experts also agreed that PRIs' role remain critical for countries' innovation and economic performance through their activities in creating, discovering, using, and diffusing knowledge and technology (OECD, 2011; 2017; Mazzoleni \& Nelon, 2007; Suzuki, Tsukada, \& Goto, 2014). On the other side, results of technological innovations from PRIs have also played a central role in achieving important societal objectives, such as economic growth and improved human well-being.

Many studies also discussed the extension of the research results into commercialization stages (Rasmussen, Mosey, \& Wright, 2011; Srivasta \& Chandra, 2012; Abbate \& Caesaroni, 2017). 
In the academic sector, including public R\&D institutions, the process of commercialization and/or bring technologies to the market place is also known as "technology transfer." (Srivastava \& Chandra, 2012; Rasmussen, Mosey, \& Wright, 2011; Wright, 2014; Simpson, 2002). Nowadays, many countries often expect that PRIs have a wider impact and are oriented towards problem-solving for their stakeholders, including community and public policy, as well as building researchers' capacity (Boaz, Fitzpatrick, \& Shaw, 2008).

Therefore, PRIs should have effective mechanisms to integrate their two main activities, research publication, and research commercialization. This has become a major challenge for PRIs, particularly when technology transfer is part of the government mandate for institutions receiving public funding for research.

Due to the importance of the PRIs' contributions to the economy and welfare of the people, knowledge, and technology transfer from PRIs to community is very important. However, the number of scientific or research articles on transfer research-based interventions into general practice at the community level are limited. Technology transfer studies from PRIs to community is not really popular compared to technology transfer research to industry. However, by knowing stage by stage of the practical experiences on technology transfer from a PRI to community, it could help policy makers and funding agencies in prioritizing their programs for community welfare or community empowerment program.

Substantial amount of research, mostly examining the factors influencing transfer of knowledge and technology from academia and public R\&D institutions to industry and small medium enterprises, occurs without mentioning how to improve the process of technology and knowledge transfer from PRIs to community (Grimaldi, Kenney, Siegel, \& Wright, 2011; Povoa \& Rapini, 2010).

Although many technology innovations are driven primarily by markets or by the users, the transfer process of technology innovation from PRIs to society is not a simple matter. The technology transfer process requires access to a number of informational, financial, and human resources (Zuniga \& Correa, 2013).

Coppola (2007) stated that technology transfer from PRIs or academia often need bridges due to the barriers faced by PRIs. Major issues from PRI's perspective are difficulties in translating ideas into marketable products. Basic R\&D is often far from marketability, therefore PRIs need further development orientation and more funds to be more 'usable' The private sector/investors also will not pick up this R\&D because it is too risky (has not been fully "applied" yet). In this situation, the 'valley of death' exists in PRIs, mostly in relation to results of R\&D commercialization to Industry. In other words, the 'valley of death' exists and prevents the progress of technology invention or innovation from PRIs to a commercially successful business or product.

Gulbrandsen (2009) mentioned that in technology transfer, the 'valley of death' is the metaphor often used to describe the gap between PRIs or academic-based innovations and their commercial application in the marketplace. PRIs and academic research is in some way cut off from the outside world. The concept of the 'valley of death' is often applied to the transfer of technology from PRIs or academia to industry or occurs within industry, while transfer of technology from PRIs to the community is mostly based on community needs, non commercial bases, and does not compete with existing technology.

Cohen (2006) further explained that communities are increasingly looking to their regional governments and universities to implement programs that stimulate the local economy. Although the idea of research institutions contributing to economic progress and public wellbeing is not necessarily new, its explicit connection to economic and community development is signaling a change in the discourse about the systems and rules for managing science and technology (S\&T).

There are several PRIs in Indonesia that are mostly publicly owned or operated to a large extent on government funding for their activities, e.g. Indonesian Institute of Sciences (LIPI), National Nuclear Energy Agency of Indonesia (BATAN) and Indonesian National Institute of 
Aeronautic and Space (LAPAN) and Agency for the Assessment and Application of Technology (BPPT) (Hermawati, Siahaan, Rosaira, Manalu, $\&$ Santoso, 2018). Their activities mostly engaged in continuous R\&D activities including basic research, applied research, and generate new knowledge in certain sectors.

Those PRIs are perhaps the ones with excellent manpower, novel ideas, and high motivation to conduct R\&D activities in Indonesia. Their contributions are not only in terms of technology innovation, but also human capital development, which is needed for sustainable development of a country.

Among their activities, they carry out 'action research' for economic growth of society or for community development. If the research is about generating knowledge, then 'action research' creates knowledge based on enquiries conducted within specific and often practical contexts. Reason and Bradbury $(2001,2)$ explain that the primary purpose of action research is to produce practical knowledge that is useful to people in the conduct of their daily lives.

Waterman, Tillen, Dickson, \& de Koning $(2001,4)$ provides a comprehensive and practical definition of 'action research', which describes, interprets and explains social situations while executing a change of intervention aimed at improvement and involvement. It is problemfocused, context specific, and future-orientated.

Action research is a group activity with an explicit value basis and is founded on a partnership action between researchers and other participants, all of whom are involved in the change process. Winter and Munn-Giddings's $(2001,8)$ provide definition of action research as a 'study of a social situation' carried out by those involved in that situation in order to solve the problems of the users or stakeholders through a better understanding, participation, improvement, reform, problem finding, problem solving, a step-by-step process, modification, and theory building.

Previously, research institutions were perceived as a source of new ideas and knowledge/ technology, where industries maximized the use of these ideas. However, now public funded $\mathrm{R} \& \mathrm{D}$ activities are increasingly expected to be relevant to public concerns, such as to improve human quality of life, environmental conditions, support policy formulation and upgrade existing industries as well as solving community problems (Boaz, Fitzpatrick, \& Shaw, 2008).

The focus of this paper is on the role of PRI ' $A$ ' in transfering the results of action research to the users, in this case the community/society. This paper also focused on understanding implications that are necessary to identifying the main components for effective technology transfer by reviewing and analyzing the main issues related to technology transfer.

Since technology transfer is also treated as underpinning factors of economic growth society, discussion has also developed around impact as a broader phenomenon and the importance of making the PRI 'A' results more visible at the community level. The case study focuses on two different action research fields that provide a reasonably inclusive picture of the ways in which research is linked and contributes to the surrounding society, so it can increase innovation and raise productivity, create better job opportunities and address societal challenges such as poverty alleviation, food security or environmental protection. The two action researches were conducted between 2010-2014.

\section{B. METHODOLOGY}

The research used 'mixed methods', which was the combination of qualitative and quantitative approaches in a single evaluation (Creswell, 2009). Almost all quantitative assessments have some measure of qualitative analysis such as by reading the project documents, project reports, and literature related to the projects as well as additional information from interviews with project staff and various beneficiaries, experts, and other stakeholders in the field.

Focus and scope of the study covered two action researches for economic growth society located in Belitung Island and Wonogiri District. The visits and revisits used a semi-structured questionnaire to identify the users and benefits of the research results as well as impacts generated from the action research. 
The quantitative data, mostly in the form of type of technologies being transferred as the numbers of products or services as results of the research beneficiaries of the projects, or networking created by the projects. Those quantitative data analysis informed were enriched by qualitative insights from the interviews results. This provides a more deep and meaningful results of analysis.

Data collection was conducted in the research centers and the project sites. Recontacting people/ experts was done over time, clarifying what had happened to the recipients of the projects and determining whether the benefit of the research spread widely towards continuous improvement in the community/micro enterprises, or provided feedback to researchers and policy makers.

The researchers interviewed 17 key persons involved in the action reseach projects, namely the research principals and coodinators of the projects, beneficiaries, as well as counterparts of the projects. Focus group discussion at the local government offices was held among management team, beneficiaries, policy makers at district government, and other stakeholders related to the project to get new ideas on the right mechanisms for the transfer of technology.

Interviews and visits to the research site took place between April and July 2017. Each interviews took place between 60-90 minutes conducted in their place. Main contents of the interview were related to transfer processes, adoption by the community, benefits to the users, and challenges and barriers in having the technology transfer from the reserchers and users point of view.

In summary, methods used in this research were

1. documentary study from journals (online and printed journals), research reports, minutes of the meetings, etc.,

2. questionnaires to project coordinators/principal researchers,

3. extensive and intensive fieldwork/observation (including surveys, interviews, etc.) to the key informants/ beneficiaries (community, SMEs, District Government) and management interviews (high eschelon/top decision makers at PRI 'A', coordinators and researchers,

4. compilation of quantitative and qualitative data analysis, and

5. focus group discussions.

\section{ANALYTICAL FRAMEWORK}

\section{Technology Transfer from PRIs to Communities}

Roessner (2000) stated that technology transfer is the formal and informal movement of know-how, skills, technical knowledge or technology from one organizational setting to another, including society. UNCTAD (2014) proposed the term of "transfer of technology" may also be applied to the process by which a technology is developed for a specific use or sector where it becomes applicable in a different productive setting. A process can take place within or across national boundaries and on a commercial or non-commercial (concessionary) basis. It may refer to the physical movement of assets or to immaterial elements such as know-how and technical information, or most often to both material and immaterial elements, and may be linked to the movement of physical persons or more specifically to the movement of a specific set of capabilities or talents. It can be estimated that the transfer was successful if the receiving entity can effectively use the technology transferred and evetually assimilate it (Ramanathan, 2008).

According to Diaconu and Dutu (2014), technology transfer should be understood as a process through which scientific and technological discoveries are incorporated into goods and services capitalized on the market and contributing to the economic development of an area, involving the transfer of intellectual property through legal means in the license agreements, know-how, franchise, and engineering. Technology transfer from donor to receiver may occur directly or through public or private technology brokers/agencies. The transfer may be originated by technology push (by the research side) or market pull (from the industry side). The technology transfer results from actions taken by various stakeholders, including recepients, suppliers, buyers, owners, 
users, and developers. Stakeholders involved in technology transfer are shown at Table 1.

Table 1. Stakeholders Involved in Technology Transfer

\begin{tabular}{|c|c|}
\hline Stakeholder Group & Members \\
\hline $\begin{array}{l}\text { Technology } \\
\text { producers }\end{array}$ & $\begin{array}{l}\text { Independent inventors, } \\
\text { researchers in universities; } \\
\text { state laboratories; private } \\
\text { laboratories }\end{array}$ \\
\hline $\begin{array}{l}\text { Technology } \\
\text { consumers }\end{array}$ & $\begin{array}{l}\text { Private sector manufacturers, } \\
\text { government agencies; intel- } \\
\text { lectual property brokers }\end{array}$ \\
\hline $\begin{array}{l}\text { Product } \\
\text { producers }\end{array}$ & $\begin{array}{l}\text { Private sector manufacturers; } \\
\text { distributors; value added } \\
\text { retailers }\end{array}$ \\
\hline $\begin{array}{l}\text { Product } \\
\text { consumers }\end{array}$ & $\begin{array}{l}\text { End-users; professional service } \\
\text { providers }\end{array}$ \\
\hline $\begin{array}{l}\text { Resource } \\
\text { providers }\end{array}$ & $\begin{array}{l}\text { Government agencies; } \\
\text { inter-governmental } \\
\text { institutions and donors; } \\
\text { financial sector; technology } \\
\text { transfer intermediaries }\end{array}$ \\
\hline
\end{tabular}

Source: Thompson (2015)

The benefits of technology transfer processes consist of improving the products, manufacturing processes, development of new products and services required by the market. Technology transfer therefore means the movement of technology, consisting of knowledge, skills, and equipment, from one entity as an originator's environment to other entities. No transfer has however taken place unless the moved technology, knowledge, skills are used.

PRIs are among others creating new knowledge, technology, and processes. On the other side, communities sometimes might need immediate products and process solutions for their necessities, in the long run they need to empower themselves to become independent communities. The process of transfering research results from PRIs to fulfill the community needs is part of what we called the application of technology transfer. At the community level, technology has been introduced to be a main factor for converting natural resources, land, capital, and manpower to improve the livelihood or completed goods. So, it can be regarded as a combination of hardware and software for production, which has been formed from four basic elements, e.g. technoware, humanware, orgaware, and inforware (UN-ESCAP, 1988). While Porter (1991) mentioned that technology is a collection of knowledge, products, processes, tools, methods, structures, and systems that are used in creating value (added) in a system.

The process of technology transfer to communities often face many challenges, such as unfavorable economic incentives and inadequate information for PRIs. Coordination among various stakeholders is also a challenge. Johnson, Gatz, and Hicks (1997) stated that recognizing the end user's needs and the context where the technology will be used is essential for the successful technology transfer to community.

Enrigues, Lorena, and Cynthia (2016) mentioned that currently, technology transfer for community needs has been evolving to something more responsible or appropriate for the context. Technology transfer for improving economic and livelihood of communities is mostly in the form of grassroots technology. Transfer of grassroots technology to meet community needs is aimed to build a strong sense of community and benefits that span across social, environmental, cultural, economic, and spiriual dimensions (Enrigues, Lorena, \& Cynthia, 2016). It is therefore, technology transfer to communities is the major consideration of PRIs, particularly in the decision making process of technology creation whether it will suit their needs, so a win-win situation could be generated and avoid dependancy. Most of the technology transfer to communities are not in the form of a very sophisticated technology, but most are in the form of intermediate or grassroots technology.

In the literature, the "Valley of Death" concept in the technology transfer exists due to the troublesome transition from technology researched and developed into marketable innovations (Auerswald \& Branscomb, 2003; Barr, Baker, Markham, \& Kingon, 2009). The concept of "Valley of Death" exists between invention and product development in a phase they called early stage technology development, and this is the stage where the technology shifts from a research practice to an industrial practice (Murphy 
\& Edwards, 2003). In most cases, the existence of this 'valley of death' is in the case of commercial research from industry or transfer of technology from PRIs and academia to the industry. The valley of death exists due to management, financial, and skill problems (Barr, Baker, Markham, \& Kingon, 2009). In the transfer of technology from PRIs to community, its concept almost does not exist, due to the technology developed and research conducted based on the community needs.

Mogavero and Shane (1982) mentioned that technology transfer models can be classified into two major categories. The first category is passive and the second is active. This classification refers to the level of activity in applying the technology in the transfer process. If the technology transfer mechanism presents the technology to the potential user without assistance regarding its application, then the mode is called passive (Figure 1).

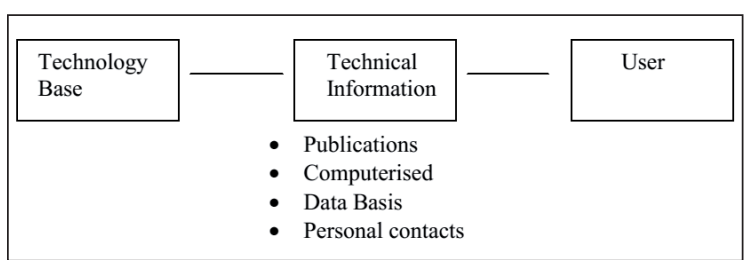

Source: Le Grange \& Buys (2002)

Figure 1. Passive Technology Transfer Mode

In the passive mode, only the technology and knowledge part of technology is transferred, the skills surrounding the technology are not transferred. On the other hand, if the provider of the technology assists with the application of the technology then the mode is called active (Figure 2). These mechanisms include training and support.

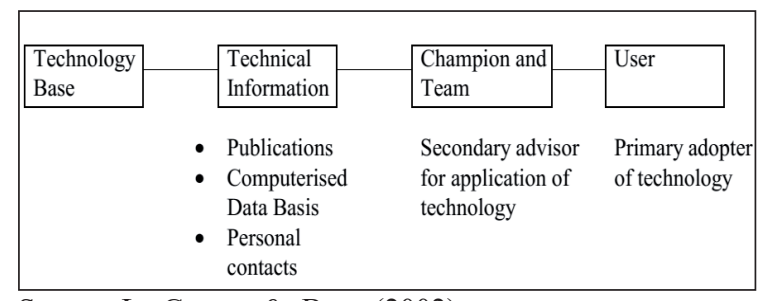

Source: Le Grange \& Buys (2002)

Figure 2. Active Technology Transfer Mode

There are very often gaps between current and new technology resulting from PRIs and what is needed by the communities, including SMEs and micro enterprises. Therefore, the researcher should recognize a need of a user/community. After defining a need he/she must work for appropriate technology that will best satisfy this need, whether to develop the new technology or improve the existing one.

Technology transfer takes place via certain means. Cooke and Mayes (1996) indicate that these means can be identified per area of technology as follows

a. Technology in the form of knowledge can be conveyed through the following means, such as scientific journals and magazines, patent, paper presentation at conferences or societies, discussion with colleagues, acquaintances, consultants, through radio and television, and courses, data packs, and service bulletins.

b. Technology in the form of skills can be conveyed by watching someone doing something in realtime or through a video or demonstration at courses and hands-on training.

c. Technology in the form of equipment is conveyed via the following mechanisms: products, through trade magazines, trade conventions, sales representatives, advertisements, and other direct forms of contact.

As the transfer process takes time, the researcher and the communities have to keep in mind the benefits of the new technology compared to the old one. Le Grange and Buys (2002) proposed the steps in technology transfer process (Figure 3 ).

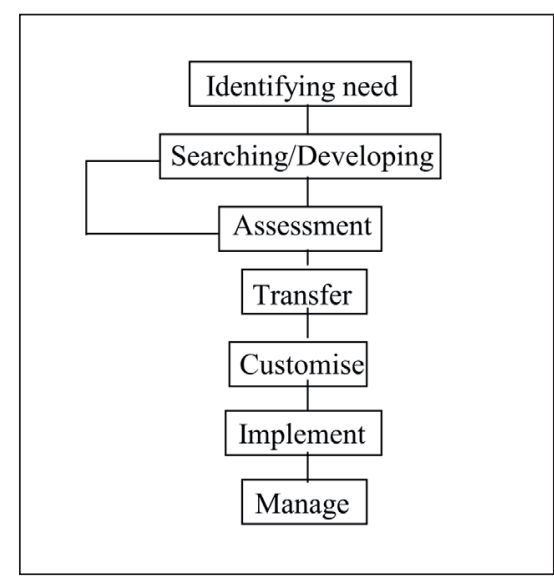

Source: Le Grange \& Buys (2002)

Figure 3. Technology Transfer Process 
Although the issue of cost may also be a barrier, working under 'proper or suitable culture' between researchers and communities is a key to success in replacing older technology in communities. In general, the transfer of technology from PRIs to community will cover funded project, research project, and management, collaboration, and networking.

Gardner, Fong, \& Huang (2010) also mention that there are several key reasons to measure the effectiveness of technology and knowledge transfer activity at PRIs, such as:

a. to demonstrate the benefits of new technology/knowledge to society,

b. to educate on society's need for innovation,

c. to ensure sufficient returns on investment,

d. to provide benchmarks for comparison across the industry,

e. to promote competition in the global market place, and

f. to support future appeals for funding.

\section{Mechanism and Barriers of Technology Transfer to Community}

The mechanism of technology transfer from PRIs to community is very challenging. In many developing countries, modern transfer of technology from PRIs (including universities) into rural communities is currently heavily supported by many external agencies including innovative firms, intellectual property consultants, business consultants, technology brokers, research, and educational institutions, private industrial enterprises, financial institutions, NGOs (organizations non-governmental), governments and international funding agencies such as World Bank and CIDA (Diaconu \& Dutu, 2014).

In the case of Small Medium Enterprises (SMEs), issue of technology transfer from PRIs is also very important, since they usually do not have their own in-house R\&D facilities. It is therefore, in general, the transformation of research results to users (practice) is part of technology transfer or technology commercialization (Figure 4).

An initiation can take place in PRIs, universities or others. Transfer of new technology/ knowledge is generally conducted to users, including to big and medium industries and community. The diffusion process of innovation in many developing country is very weak and poorly investigated by researchers. A question of the successful transfer of technology/knowledge is actually a matter of cooperation and partnership between the owner of new technology/knowledge and the users or community (Le Grange \& Buys, 2002)

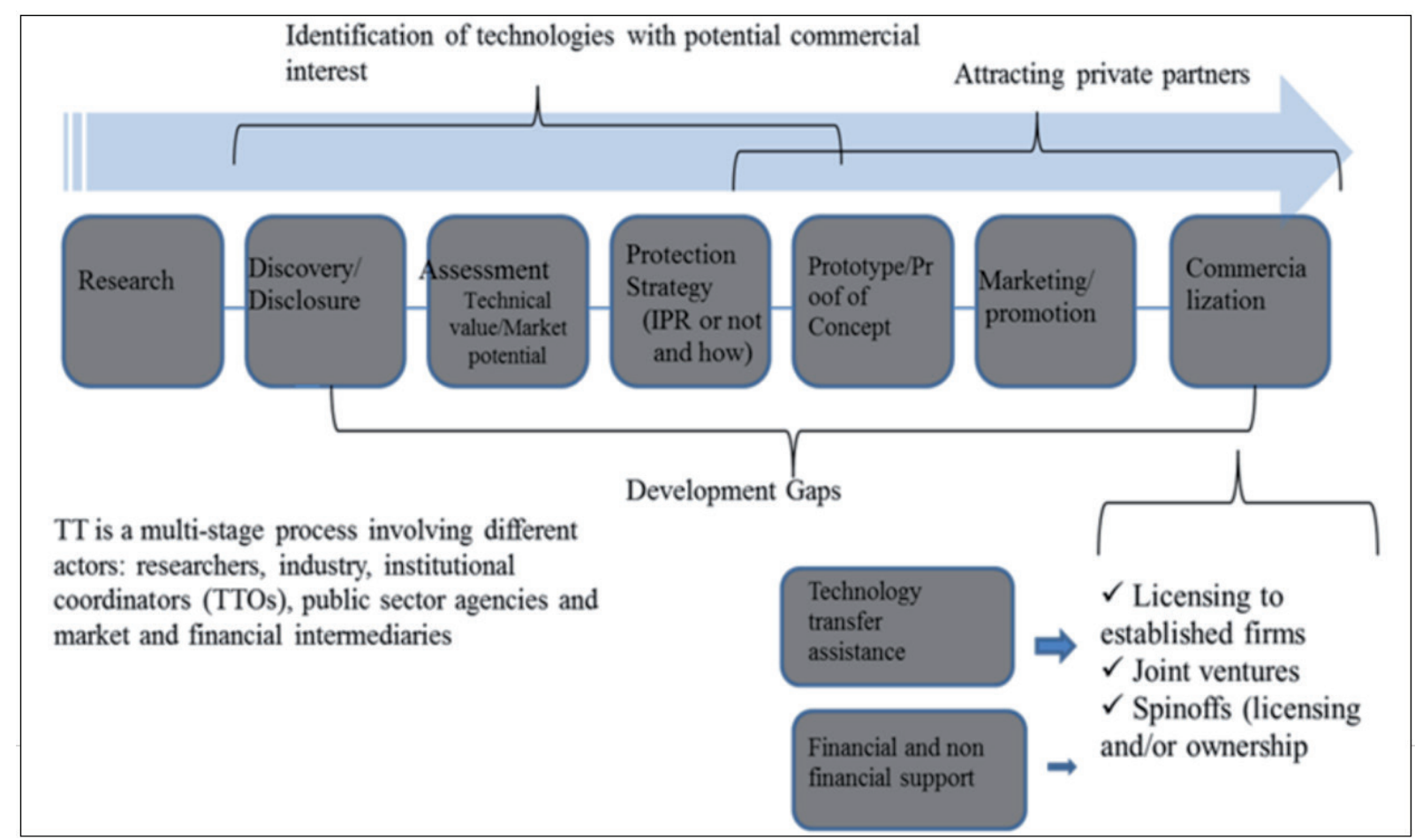

Source: Zuniga \& Correa (2013)

Figure 4. The Process of Technology Commercialization 
In order to maintain sustainability of the technology acceptance, particularly as the community level, several considerations should be taken as this is also to mobilize transfer of $R \& D$ results, such as:

a. establishing revolving funds program,

b. enticing commercial banks to support new technologies purchases,

c. supporting the income base of the end-use group, and

d. supporting access to capital, so the community who own businesses involving transfered technologies.

Meanwhile, experts have identified several mechanisms for technology transfer to community namely those dissemination of certain technologies from PRIs to community as users (Diaconu, \& Dutu, 2014; Vac \& Fitiu, 2017) (Table 2).

Table 2. Technology Transfer Mechanisms of PRIs

\begin{tabular}{|c|c|c|}
\hline $\begin{array}{l}\text { Type of } \\
\text { Mecha- } \\
\text { nism }\end{array}$ & Parties involved & Description \\
\hline $\begin{array}{l}\text { Direct to } \\
\text { the users }\end{array}$ & $\begin{array}{l}\text { None - TT } \\
\text { conducted by } \\
\text { single institutions }\end{array}$ & $\begin{array}{l}\text { Transfer is conducted } \\
\text { directly to the users }\end{array}$ \\
\hline $\begin{array}{l}\text { Conducted } \\
\text { with partner }\end{array}$ & $\begin{array}{l}\text { Another } \\
\text { partners, could } \\
\text { be NGOs, } \\
\text { universities, } \\
\text { companies or } \\
\text { other institutions }\end{array}$ & $\begin{array}{l}\text { This type of transfer } \\
\text { generally conducted in } \\
\text { fundamental research } \\
\text { for skill training }\end{array}$ \\
\hline $\begin{array}{l}\text { Conducted } \\
\text { by involving } \\
\text { multi } \\
\text { institutions }\end{array}$ & $\begin{array}{l}\text { Local govern- } \\
\text { ment offices, } \\
\text { companies, uni- } \\
\text { versities, NGOs, } \\
\text { Community } \\
\text { groups, etc. }\end{array}$ & $\begin{array}{l}\text { Many of the PRI's } \\
\text { projects started } \\
\text { cooperate with other } \\
\text { institutions/ stakehold- } \\
\text { ers from the beginning } \\
\text { of the project. }\end{array}$ \\
\hline $\begin{array}{l}\text { Licensing/ } \\
\text { Patent } \\
\text { scheme }\end{array}$ & $\begin{array}{l}\text { Mostly compa- } \\
\text { nies }\end{array}$ & $\begin{array}{l}\text { New technology is } \\
\text { licensed by other par- } \\
\text { ties, usually companies }\end{array}$ \\
\hline $\begin{array}{l}\text { Document } \\
\text { transfer/ } \\
\text { know-how } \\
\text { contract }\end{array}$ & $\begin{array}{l}\text { Mostly compa- } \\
\text { nies or research } \\
\text { institutions }\end{array}$ & $\begin{array}{l}\text { Schemes of techno- } \\
\text { logical flows. Sketches, } \\
\text { documents in the } \\
\text { contract of know-how }\end{array}$ \\
\hline $\begin{array}{l}\text { Sell and buy } \\
\text { new pro- } \\
\text { ducts based } \\
\text { contract }\end{array}$ & $\begin{array}{l}\text { Companies, } \\
\text { research } \\
\text { organization }\end{array}$ & $\begin{array}{l}\text { This activity may be } \\
\text { accompanied by staff } \\
\text { trainings }\end{array}$ \\
\hline $\begin{array}{l}\text { Dissemi- } \\
\text { nation }\end{array}$ & $\begin{array}{l}\text { Various organiza- } \\
\text { tions }\end{array}$ & $\begin{array}{l}\text { Conferences, scientific } \\
\text { articles published in } \\
\text { professional journals, } \\
\text { technical reports, etc. }\end{array}$ \\
\hline
\end{tabular}

Source: Diaconu \& Dutu (2014); Vac \& Fitiu (2017)
The mechanism for technology transfer mentioned in Table 2 includes:

a. cooperation with other parties (companies, central and local government, NGOs, and international agencis) in the development of research programs for the introduction of new types of products and services for certain target groups of community,

b. patenting and licensing the results of technological development process in an organization to be operated by another organization (companies),

c. transferring documents, such as schemes of technological flows, sketches, and documents in the contract of know-how,

d. selling, purchasing, and importing means of production required to obtain new products,

e. cooperation between two partners in fundamental research for skills training and skills for product development,

f. cooperation in applied research that are done between new organizations like start-ups and universities,

g. cooperation in product development as an activity carried out mainly by industrial enterprises,

h. agreement based on product subcontracting established between the beneficiary and a specialized design firm able to achieve the product based on the specifications of the project; this activity may be accompanied by staff training to ensure the transfer of skills and abilities among the transfer participants, and

i. dissemination of information through conferences, scientific articles published in professional journals, technical reports.

The classifications of barriers has been proposed by many scholars (Cooke \& Mayes, 1996; Mazurkiewicz \& Poteralska, 2017; Burhanuddin, Arif, Azizah, \& Prabuwono, 2009; Barbolla \& Corredera, 2009). They particularly identified the barriers related to the $R \& D$ institutions, their partners as well as users, among others related to the following point of view

a. management attitudes,

b. poor technical research, 
c. financial problems,

d. resistance to change,

e. poor information flows,

f. poor communication with the users or within $\mathrm{R} \& \mathrm{D}$ institutions,

g. lack of time in managing the technology,

h. too expensive to be implemented or to produce,

i. current product/procedures does not meet the needs,

j. too much red tape,

k. inadequate of knowledge and skills, and

1. others problems related with culture, political, and institutional/organisational related barriers.

Some of these aspects may have a greater influence on transfer of technology as compared to others, depending on the technology transfer situation (local and national).

\section{Public Research Institutes}

In developing countries, public research institutions (PRIs) are considered as primary tools for government in enhancing knowledge, technology, and innovation as well as to spur national economic development and welfare of the people (OECD, 2011, 2017; Mazzoleni \& Nelson, 2007; Intarakumnerd \& Goto, 2016). The PRI activities in creating, discovering, using, and diffusing knowledge and technology (including in research, development, and others, such as dissemination of technology), are mostly funded by government. In Indonesia, the PRIs that are heavily funded by the government for their activities, among others are LIPI, BATAN, LAPAN, and BPPT (Hermawati, Siahaan, Rosaira, Manalu, \& Santoso, 2018). In developed countries, PRIs also have role in providing direct R\&D supports to business firms and public authorities (Maass, 2003).

Currently, PRIs need to play a more active role in their relationship not only with industry, but also with society, in order to maximize the utilization of their research results as well as in the realizing economic, social, environmental, and cultural benefits for the community development. PRIs are also increasingly expected to have researchers and its results are more relevant to public concerns to improve human quality of life, poverty alleviation and environmental conditions, support policy formulation, and upgrade existing industries.

PRIs are also considered as an integral part of the national innovation systems (Intarakumnerd \& Goto, 2016; Cohen, Nelson, \& Walsh, 2002). It is therefore, the roles of PRIs in linking various actors, such as users, producers, and other stakeholders, to boost innovation in the country. Boaz, Fitzpatrick, and Shaw (2008) stated that PRIs should be oriented towards problem-solving with their stakeholders and build researcher capacity.

Many of the most important outcomes of PRIs are in the form of new knowledge, skills, and experience, which are considered as intangible and unquantifiable, such as changes in skill, knowledge, attitude, behaviour, condition, or life status for program participants (Siahaan, Hermawati, Rosaira, Manalu \& Santoso, 2017). The PRIs' outcomes should also demonstrate the value of government investment/funding as well as improved programme efficiency and effectiveness.

\section{CASE STUDIES' FINDINGS}

\section{Food Processing Technology Project}

One of the results of action research project at PRI 'A' is food processing technology. After an in-depth interview with the project management and visited the project sites, we found that results of this project have been adopted by the users/ communities for more than five years. Consequently, they have been generating some impacts to the users and the researchers, the project is also considered as a sustainable project of PRI 'A' (Hermawati, Siahaan, Rosaira, Manalu, \& Santoso, 2018).

The action project was conducted by researchers ( 2 masters) and 2 undergraduates as technical assistants from Development Center of Appropriate Technology of PRI ' $A$ '. The project was conducted within 2010-2014. Various proccessing food technologies resulted from this project, such as food technology for making fish crackers, squid crackers and fruit chips, added value local products. Those food processing technologies were developed based on the communities' need or local micro enterprises' need of 
Selat Nasik at Belitung Island. Therefore, those final technology developments were transferred to the community in Selat Nasik subdistric, Belitung District, Bangka Belitung Island.

In the technology transfer process, the center used the scheme of cooperation and interaction (Vac \& Fitiu, 2017). The center cooperates with local government of Belitung Province and local SMEs. Many types of training for entrepreuners in micro enterperises and small to medium enterprises (SMEs) were given as part of the technology transfer agreement, including training related to the management and commercialization of their local products, such as crackers, pepper, honey, salt fish, and many other local products.

The researchers also assisted them in packaging and business management, including making their own brand and registering to get the certificates from BPOM (Agency for Drug and Food Processing) and Depkes (Ministry of Health). Since the beginning, the researchers have worked very closely with the community. They have identified very well the technological needs of the community. The mechanism of technology transfer is shown in Table 3.

Table 3. Technology Transfer Activities at the Center of Appropriate Technology, PRI 'A'

\begin{tabular}{|l|l|l|}
\hline Flow of Entity & Scheme of TT & Stakeholders Involved \\
\hline Technology/Equipment & $\begin{array}{l}\text { Direct to users/SMEs/ } \\
\text { community groups }\end{array}$ & $\begin{array}{l}\text { Users (SMEs and } \\
\text { community groups) }\end{array}$ \\
\hline $\begin{array}{l}\text { New knowledge, new methods, } \\
\text { skills, etc., that is applicable } \\
\text { for users }\end{array}$ & $\begin{array}{l}\text { Through trainings and in } \\
\text { cooperation with: } \\
\text { Local government, } \\
\text { universities and } \\
\text { commuunity groups }\end{array}$ & $\begin{array}{l}\text { Local government } \\
\text { Universities } \\
\text { Community groups }\end{array}$ \\
\hline $\begin{array}{l}\text { Dissemination of new } \\
\text { knowledge }\end{array}$ & $\begin{array}{l}\text { Through: } \\
\text { Conferences, journals, } \\
\text { reports, radio, TV, etc. }\end{array}$ & $\begin{array}{l}\text { Multi stakeholders } \\
\text { including media }\end{array}$ \\
\hline \multicolumn{2}{|l|}{ Note: TT: Technology Transfer } &
\end{tabular}

During 2010-2014 about 41 micro and SMEs, 25 households with total of 150 persons involved in the training held by this project (Hermawati, Siahaan, Rosaira, Manalu, \& Santoso, 2018). Adoptions of the new appropriate technologies from this center have increased the ability of SMEs to replicate the technologies, as well as increased their production and enlarged their market. This is considered as one of the success of the project. A policy at the local government level was issued in 2015 to determine Selat Nasik as one of the tourist destination areas in Bangka Belitung.

\section{Land Microbes for Organics Fertilizers Project}

The project of selected land microbe treatments for organic fertilizers was conducted by researchers (2 Ph.D., 1 master) and 2 technical assistants from the Biology R\&D Institution of PRI 'A'. The project was conducted from 2008 until 2014. This research was fully funded by the government. Results of this research are a new formula of liquid and granule organic fertilizers as well as innovative equipment/technology for blending the organic fertilizer and a patent for new formula (Hermawati, Siahaan, Rosaira, Manalu, \& Santoso, 2018).

Transfer of the research results to the community was done through three schemes, namely

a. directly to the farmers groups;

b. collaboration with local government and farmers groups;

c. patent and license by industry. Two firms have lisenced the patent of liquid organic fertilizer.

d. Technology transfer to the users and industry are the new formula and blending equipment for organic fertilizer. The mechanism of technology transfer is shown in Table 4.

Table 4. Technology Transfer Activities at the Center of Biology R\&D Center of PRI'A'

\begin{tabular}{|l|l|l|}
\hline Flow of Entity & Scheme of TT & Stakeholders Involved \\
\hline Technology/Equipment & $\begin{array}{l}\text { Direct to users/SMEs/ } \\
\text { community groups }\end{array}$ & $\begin{array}{l}\text { Users (SMEs and } \\
\text { community groups) }\end{array}$ \\
\hline $\begin{array}{l}\text { New knowledge, new methods, } \\
\text { skills, etc., that is applicable } \\
\text { for users }\end{array}$ & $\begin{array}{l}\text { Through trainings and in } \\
\text { cooperation with: } \\
\text { Local government, } \\
\text { universities and } \\
\text { commuunity groups }\end{array}$ & $\begin{array}{l}\text { Local government } \\
\text { Universities } \\
\text { Community groups }\end{array}$ \\
\hline Patent/Licensing & Sold/license to industry & Industry \\
\hline $\begin{array}{l}\text { Dissemination of new } \\
\text { knowledge }\end{array}$ & $\begin{array}{l}\text { Through: } \\
\text { Conferences, journals, } \\
\text { reports, radio, TV, etc. }\end{array}$ & $\begin{array}{l}\text { Multi stakeholders } \\
\text { including media }\end{array}$ \\
\hline \multicolumn{2}{|l|}{ Note: TT : Technology Transfer }
\end{tabular}

The technology and new formula have been adopted by various farmer groups in more than 25 districts in West, Central and East Jawa Provinces, East Kalimantan and West Sumatera Provinces.

In the introduction stage of the research results, the researchers developed good networks with local government and local leaders, especially to convince farmers in that area to replace chemical fertilizer with organic one. The researchers held two to three training sessions for 
selected farmers and developed a demonstration plot as a sample of rice fields or fruits plantation with organic fertilizers. Until 2016, more than 2.000 farmers have attended the training courses held by this project, mostly on producing liquid organic fertilizer (Hermawati, Siahaan, Rosaira, Manalu, \& Santoso, 2018).

The success of this technology transfer was shown by many positif impacts after the farmers using it, including new knowledge and skills, increased fertility of their rice fields and agriculture land, as well as creating better conditions of the environment and surrounding. At last, the farmers decreased the use of chemical fertilizers by $40 \%$ and increased their household's income by average about $30 \%$.

\section{E. DISCUSSION}

The broader impact of technology transfer from PRI to community emerges as a result of researchers working on their research-based knowledge or expertise based on society needs. The first premise for this successful technology transfer to community is that the new knowledge, technology, know-how, understanding or perspective produced by research is somehow being conveyed beyond usual schemes (mostly non-contract based) and is utilized by the users (including community) or to solve their problems. The process of transfer of technology from the perspective of the institution (PRI 'A'), as shown in Table 3 and 4, can be explained.

1. Direct transfer to the users (community). Technology as the research results, come into use directly to the users without formal contract. There are a lot of underpinning research and development in the background.

2. Through cooperation and interaction. Researchers work together, discuss, and exchange knowledge with other stakeholders, such as business and industry, public authorities, education, NGOs, or others professional practitioners including funding agencies in transferring their research results to community.

3. The proficient people. Research-based knowledge, expertise, vision, and skills are conveyed by individual people who act as local agent in delivering the research results.

4. Patent and licensing the technology by Industries.

5. Dissemination of information through conferences, scientific articles published in professional journals and technical reports.

6. The success of technology transfer also links to research topics and objectives, and especially to where, when and by whom the research is utilized. Is the research undertakings based on or may be interventions in society? Identify the potential users and beneficiaries of our research activities as well as understand the environment in which they operate many fields of science and technology is very significantly important.

Therefore, most of the technology transfer from this PRI to community emerges through a complex process that involves, not only researchers and research organisations, but also other factors, such as economic or societal circumstances, timing and pace of needs for new technology and knowledge, corporate IPR environments, government policies and stakeholders.

Furthermore, another factor behind the success of technology transfer to community also revealed that the technology, which resulted from the research, should fit with their needs through consultation with the users. Creating technology or products for community may need special attention, so sustainability of the technology or scaling up of the technology can be done. Therefore, the criteria of research should include the following

1. affordability is the degree to which a good or technology is affordable to users at the low end of the market;

2. acceptability is the extent to which users are willing to consume, use, distribute or sell a product or service;

3. availability is the extent to which users are able to acquire and use a product or service;

4. awareness refers to what users know about the technology, products or services you transfer. 
Results of the study also revealed that there are several factors identified as barriers in conducting the technology transfer from PRIs to community. The main problem with technology transfer arise because it is entrusted to research institutions or research funding bodies. In fact, research results for commercialisation requires commercial skills, and should be handled by independent commercial bodies that have the requisite commercial skills.

Research activities at PRIs and commercialising the results of the researches are two entirely different processes and required entirely different skills. Commercialisation requires commercial expertise.

Therefore, the process of technology transfer can fail due to many reasons that can come internally from PRI's or from the users perspectives. Problems arise from internal PRI 'A', among others are

1. lack of qualified researchers who engage in entrepreneurial endeavors and technology commercialization,

2. dissemination the results of projects requires specialised marketing skills, which is often missing in research entities,

3. a clear legal framework regarding the creation and exploitation of intellectual property and patents from research,

4. lack of a plan for the implementation of research results or business plan often not included in the research activities,

5. having financial problems in scaling up the technology,

6. lack of integrated policy and support for the transfer of technology to community,

7. lack of connectedness with other institutions or partnership,

8. lack of trust from the users,

9. lack of technology assessment including technology readiness level and technology valuation,

10. there are often problems with selecting the most appropriate technology transfer mechanisms, and
11. no regular monitoring and evaluation after the transfer process.

Problems that arise from the users are

a. lack of absorptive capacity,

b. the users are not able to discern the level and characteristics of the technology needed,

c. management attitudes at the users levels, particularly in managing technology for user's group,

d. some of the people in that areas have a resistancy to change,

e. no sufficient assistance for farmers/users after they finished training, and

f. too expensive for most of the farmers/users.

g. Those problems should be recognized before the decision of developing the technology is made.

\section{F. CONCLUSION AND IMPLICATION}

The two cases of the technology transfer from PRI 'A' to community are on food processing technology and land microbes for organic fertilizers. The research provides evidence that the technology transfer is conducted with the schemes, (1) direct to the users, (2) document transfer/training in cooperation with multistakeholders/institutions, (3) patent and licensing and (4) dissemination. PRI 'A' cooperates with local government, NGOs, farmers groups and SMEs.

Adoptions of these new appropriate technologies from the centers have increased ability of SMEs and farmers to replicate the technologies, as well as increased their production and enlarged their market. The success of this technology transfer was shown by many positive impacts after the farmers/SMEs used it, including new knowledge and skills, increased new knowledge and skills, their productivity, fertility of their rice fields and agriculture land, as well as creating better condition of environment and surrounding. As a result, the farmers decreased the use of chemical fertilizers by $40 \%$ and increased their household's income by average about $30 \%$.

The study tried to enrich the literature related to technology transfer from PRI to community. However, the case studies demonstrated that several barriers exist in doing the technology 
transfer to community. Barriers are coming from the instution (PRI 'A') as well as from the users perpsectives, such as lack of technology assessment including technology readiness level and technology valuation, lack of qualified researchers who engage in entrepreneurial endeavors and technology commercialization, management attitudes at the users levels, financial problems in scaling up the technology, resistancy to change, no sufficient assistance after they finished training, too expensive for most of the farmers/users, and no regular monitoring and evaluation after the transfer process.

To avoid the 'valley of death' in commercializing research results, get technology transfer out of the hands of bureaucracies, research funding bodies and the government and put the process into the independent institution or the private sector. Implications of the technology transfer to the community are that PRI 'A' should improve their research policy and management. PRI 'A' through their researhers should consider users (SMEs and farmers) as the central (most important) component of the research decision. They are the final users of their research results (innovation technology/processes). Beside that, commitment of researchers, support and improve link with other actors, stakeholders and society, as well as increase capacity of the users.

\section{ACKNOWLEDGEMENT}

I extend my gratitude to my collagues at Pappiptek LIPI, namely Mr. Siahaan, Ms. Rosaira, Mr. Manalu and Mr. Santoso, for their valuable discussion during the research process.

\section{Notes:}

i. Main source of the data used in this article was based on the research funded and conducted by Pappiptek LIPI in 2016 entitled Evaluasi Dampak Program Kompetitif LIPI Tahun 2010-2014 (Impact Evaluation of LIPI's Competitive Program for the year of 2010-2014).

iii. This article is different from the previous one entitled Outcome and Impact Based Evalution of Research Program Implementation: A Case of Indonesian Public Research Institute, which appeared in Journal of Science, Technology, and
Innovation Policy and Management 3(1) 2018, that viewed from evaluation perspective, while this article use the lens of technology transfer concept.

\section{REFERENCES}

Abbate, T. \& Cesaroni, F. (2017). The market orientation of academic spin-off firms. Int. J. Entrep. Innov. Manag., 21, 395-421. [doi:10.3390/ su9101808].

Auerswald, P. E. \& Branscomb, L. M. (2003). Valleys of death and Darwinian seas: Financing the invention to innovation transition in the United States. The Journal of Technology Transfer, 28(3-4), 227-239. https://doi. org/10.1023/A:1024980525678

Barbolla, A. B. M. \& Corredera, J. R. C. (2009). Critical factors for success in university-industry research projects. Technology Analysis \& Strategic Management, 21(5).

Barr, S. H., Baker, T., Markham, S. K., \& Kingon, A. I. (2009). Bridging the Valley of Death: Lessons learned from 14 years of commercialization of technology education. Academy of Management Learning \& Education, 8(3), 370-388.

Boaz, A., Fitzpatrick, S., \& Shaw, B. (2008). Assessing the impact of research on policy: A review of the literature for a project on bridging research and policy through outcome evaluation. Final Report under Defra Research Contract WR0808. Retrieved on January 15th 2018 from http://www.psi.org.uk/pdf/2008/bridgingproject_report.pdf.

Bigliardi, B., Galati, F., Marolla, G., \& Verbano, C. (2015). Factors affecting technology transfer offices' performance in the Italian food context. Technol. Anal. Strateg. Manag., 27, 361-384.

Burhanuddin, M. A., Arif, F., Azizah, V., \& Prabuwono, A. S. (2009). Barriers and challenges for technology transfer in Malaysian small and medium industry. Proceedings International Conference on Information Management and Engineering, ICIME 2009 (258-261). Piscataway, NJ: IEEE.

Cohen, M. A. (2006). Economic development from universities. Licensing Executive Society, 27-28.

Cohen, W. M., Nelson, R. R., \& Walsh, J. P. (2002). Links and impacts: the influence of public research on industrial R\&D. Management Science, 48(1), 1-23. http://dx.doi.org/10.1287/ mnsc.48.1.1.14273. 
Cooke, I. I. E. \& Mayes, P. (1996). Introduction to innovation and technology transfer. London: Artech House.

Coppola, N. (2007). Communicating green innovation technology: Transfer in a university businessgovernment consortium. Comparative Technology Transfer and Society, 5(3), 233-252. doi: 10.1353/ctt.2007.0030.

Creswell, J. W. (2009). Research design: Qualitative, quantitative, and mixed methods approaches ( $3^{\text {rd }}$ Ed.). Thousand Oaks, California, USA: SAGE Publication.

Cuciureanu, G. \& Ungur, C. (2014). Allocation of public funds for research and development in a small country: The case of Moldova. Journal of Applied Economic Sciences, IX2(28), 165-180.

Diaconu, M. \& Dutu, A. (2014). Transfer of technology: Mechanism of modern university with community connection. Scientific Bulletin Economic Sciences, 13(2), 22-30. Retrieved on July $5^{\text {th }} 2018$ from http://economic.upit.ro/ buletin_cd/buletin_2014_2.pdf\#page $=24$.

Enrigue, V., Lorena, R., \& Cynthia, A. (2016). The technology transfer system in communities, product versus processes. Procedia Engineering, 145, 364-371. [doi:10.1016/j.proeng.2016.04.091].

Etzkowitz, H. (2004). The evolution of the entrepreneurial university. Int. J. Technol. Glob., 1(1), 64-77. doi: 10.1504/IJTG.2004.004551

Galati, F., Bigliardi, B., Petroni, A., \& Marolla, G. (2017). Which factors are perceived as obstacles for the growth of Italian academic spin-offs? Technol. Anal. Strateg. Manag. 29(1), 84-104.

Gardner, P. L., Fong, A. Y., \& Huang, R. L. (2010). Measuring the impact of knowledge transfer from public research organisations: a comparison of metrics used around the world. International Journal of Learning and Intellectual Capital, 7(3-4), 318-327. https://doi. org/10.1504/IJLIC.2010.034371.

Grimaldi, R., Kenney, M., Siegel, D. S., \& Wright, M. (2011). 30 years after Bayh-Dole: Reassessing academic entrepreneurship. Research Policy, 40(8), 1045-57. http://www.sciencedirect.com/ science/article/pii/S0048733311000874.

Gulbrandsen, K. E. (2009). Bridging the valley of death: The rhetoric of technology transfer (Dissertation), Iowa State University, Iowa. https://lib.dr.iastate.edu/etd/10740.

Hermawati, W., Siahaan, S., Rosaira, I., Manalu, R., \& Santoso, A. (2018). Outcome and impact based evalution of research program implementation:
A case of Indonesian public research institute. Journal of Science, Technology, and Innovation Policy and Management, 3(1), 17-34. http:// dx.doi.org/10.14203/STIPM.2018.132.

Intarakumnerd, P. \& Goto, A. (2016). Role of public research institutes in national innovation systems in industrialized countries: The cases of Fraunhofer, NIST, CSIRO, AIST, and ITRI. Research Policy, 47(7), 1309-1320.

Johnson, S. D., Gatz, E. F., \& Hicks, D. (1997). Expanding the content base of technology education: Technology transfer as a topic of study. Journal of Technology Education, 8(2), 35-49.

Le Grange, L. I. \& Buys, A. J. (2002). A review of technology transfer mechanisms. South African Journal of Industrial Engineering. 13, 1, 81-100 http://sajie.journals.ac.za.

Maass, G. (2003). Funding of public research and development: Trends and changes. OECD, Journal on Budgeting, 3(4), 41-69, http:// dx.doi.org/10.1787/budget-v3-art22-en.

Mazzoleni, R. \& Nelson, R. R. (2007). Public research institutions and economic catch-up. Research Policy, 36(10), 1512-1528 https:// doi.org/10.1016/J.respol.2007.06.007.

Mazurkiewicz, A. \& Poteralska, B. (2017). Technology transfer barriers and challenges faced by R\&D organisations. Procedia Engineering, $182,457-465$.

Mogavero, L. N. \& Shane, R. S. (1982). What every engineer should know about technology transfer and innovation. Boca Raton, Florida, USA: CRC Press.

Munari, F., Sobrero, M., \& Toschi, L. (2017). Financing technology transfer: Assessment of university-oriented proof-of-concept programmes. Technol. Anal. Strateg. Manag. 29(2), 233-246.

Murphy, L. M. \& Edwards, P.L. (2003). Bridging the Valley of Death: Transitioning from public to private sector financing. Colorado, USA: National Renewable Energy Laboratory Golden.

OECD. (2011). Public research institutions: mapping sector trends. Paris, France: OECD Publishing. Retrieved on January 15 2018 from https:// www.oecd.org/sti/sci- tech/48795219.pdf.

OECD. (2017). The role of public research institutions in the Finish innovation system (Chapter 4). In OECD Review of Innovation Policy: Finland 2017 (89-126). Paris, France: OECD Publishing. doi: http://dx.doi. org/10.1787/9789264276369-7-en. 
Porter. M. E. (1991). Towards a dynamic theory of strategy. Strategic Management Journal, 12, 95-117. http://dx.doi.org/10.1002/smj. 4250121008.

Póvoa, L. M. C. \& Rapini, M. S. (2010). Technology transfer from universities and public research institutes to firms in Brazil: What is transferred and how the transfer is carried out. Sci. Public Policy, 37, 147-159.

Ramanathan, K. (2008). An overview of technology transfer and technology transfer models. In Ramanathan K. (Ed.), Overview of technology transfer and small \& medium enterprises in developing countries. New Delhi: Asian and Pacific Centre for Transfer Technology.

Rasmussen, E., Mosey, S., \& Wright, M. (2011). The evolution of entrepreneurial competencies: a longitudinal study of university spin-off venture emergence. Journal of Management Studies, 48(6), 1314-1345.

Reason, P. \& Bradbury, H. (2008). The SAGE handbook of action research: Participative inquiry and practice ( $2^{\text {nd }}$ Ed.). London: SAGE Publications Inc.

Reason, P. \& Bradbury, H. (Eds). (2001). The SAGE handbook of action research: Participative inquiry and practice (11 $1{ }^{\text {st }}$ edition). London: SAGE Publications Ltd.

Roessner, J. D. (2000). Technology transfer. InHill, C. (Ed.), Science and technology policy in the US: A time of change. London: Longman.

Siahaan, S., Hermawati, W., Rosaira, I., Manalu, R., \& Santoso, A. (2017). Analisis dampak program kompetitif LIPI tahun 2010-2014 (Techincal research report No. 2018-01-01-02)Jakarta: Pappiptek LIPI.

Simpson, D. D. (2002). A conceptual framework for transferring research to practice. Journal of Substance Abuse Treatment, 22(4), 171-182.

Sharif, M. N. (1983). Management of technology transfer and development. Bangkok, Thailand: Regional Centre for Technology Transfer.

Srivastava, P. \& Chandra, S. (2012). Technology commercialization: Indian university perspective. $J$. Technol. Manag. Innov., 7(4).
Thompson, D. (2015). Technology transfer and commercialization [Lecture PowerPoint slides]. http://www.scienceportal.org.by/upload/2015/ June/Inconet $\% 20$ EaP\%20-\%20Presentation/8\%20Thompson_Tech $\% 20$ Transfer $\% 20$ and\%20Commercialisation.pdf.

Suzuki, J., Tsukada, N., \& Goto, A. (2014). Innovation and public research instiutes: Case of AIST, RIKEN, and JAXA (RIETI Discussion Paper Series 14-E-021). Tokyo, Japan: Research Instituteof Economy, Trade and Industry.

UN-ESCAP. (1988). Technology atlas project: A framework for technology based development technology capability assessment. Bengalore: APCTT.

UNCTAD. (2014). Transfer of technology and knowledge-sharing for development: Science, technology and innovation issues for developing countries. Geneva, Switzerland: United Nations Conference on Trade and Development.

Vac, C. S. \& Fitiu, A. (2017). Building sustainable development through technology transfer in a Romanian University. Sustainability, 9(11), 2042. doi:10.3390/su9112042.

Waterman, H., Tillen, D., Dickson, R., \& de Koning, K. (2001) Action research: A systematic review and assessment for guidance'. Health Technology Assessment, 5(23).

Winter, R. \& Munn-Giddings, C. (2001). A Handbook for action research in health and social care. London \& New York: Routledge.

Wright, M. (2014). Academic entrepreneurship, technology transfer and society: Where next? Journal of Technology Transfer, Springer, 39(3), 322-334, June. doi: 10.1007/s10961012-9286-3.

Zuniga P. \& Correa, P. (2013). Technology Transfer from Public Research Organizations: Concepts, Markets, and Institutional Failures. Washington, USA: World Bank. Retrieved on June $24^{\text {th }} 2018$ from https://www.innovationpolicyplatform. org/sites/default/files/rdf_imported_ documents/TechnologyTransferFromPublicResearchOrganizations.pdf. 